\title{
WIND CURRENTS, TIDAL STREAMS AND PLANKTON OFF THE NORTHUMBER- LAND COAST
}

\author{
By Frank Evans \\ The Dove Marine Laboratory, Cullercoats*
}

(Text-figs. $\mathrm{I}-7$ )

Investigations of the water movements off the southern Northumberland coast have until now been confined to the surface region. While important for navigational and similar purposes such investigations can give us no more than an indication of the total water flow along the coast nor can they elucidate the effects of currents on planktonic organisms which spend part or all of their existence away from the surface. It is for the latter reason that the series of investigations of sea surface currents made aboard the R.V. 'Alexander Meek' in 1956-7 (Evans, 1957) has now been supplemented by further series at two deeper levels.

The work of measurement was again undertaken on the stretch of coast between the River Tyne entrance ( $55^{\circ} \mathrm{or}^{\prime} \mathrm{N} . \mathrm{I}^{\circ} 24^{\prime}$ W.) and Newbiggin Point $\left(55^{\circ} \mathrm{II}^{\prime} \mathrm{N} ., \mathrm{I}^{\circ} 30^{\prime} \mathrm{W}\right.$.) at a distance of about a mile from the shore. There now exist for this area records of (aperiodic) wind currents and tidal streams for 2 fathoms below the surface, for 6 fathoms below the surface and for approximately 3 fathoms off the bottom. In the work to be described the method used in measuring water flow followed that of the $1956-7$ series; the track of a large, freely drifting drogue and buoy was plotted over half a lunar day. This was done to isolate the wind current from the general flow, observations beginning at various states of tidal stream and continuing for between 12 and $\mathrm{I} 3 \mathrm{~h}$, the exact period to be spent in tracking the buoy being determined from an inspection of the tide tables.

A description of the form of drogue and buoy used has been given in my earlier account; briefly, each drogue was an open-ended box $4 \mathrm{ft} 6 \mathrm{in}$. high, of wood and canvas, cross-stayed with steel bar and attached by $\mathrm{I}$ in. circumference wire to a fisherman's dan buoy. Using this equipment runs at 2 and 6 fathoms were made by interposing the appropriate length of wire between the buoy and the suspended drogue. Runs with the drogue riding approximately 3 fathoms off the bottom were accomplished in the following way: a wire I5 fathoms long was used, this being 3 fathoms less than the extreme depth of water in which the gear was worked. The wire was shackled

\footnotetext{
* Present address: University College, Achimota, Ghana.
} 
to both buoy and drogue, and close beneath the buoy a bight was taken out of the wire and stopped off with a bulldog grip (Figs. I \& 2). The effective length of wire between the buoy and the drogue could be increased or decreased by slacking back the bulldog grip and adjusting the length of the bight. During the work soundings were taken on the ship's echo sounder and the length of wire in use varied accordingly.

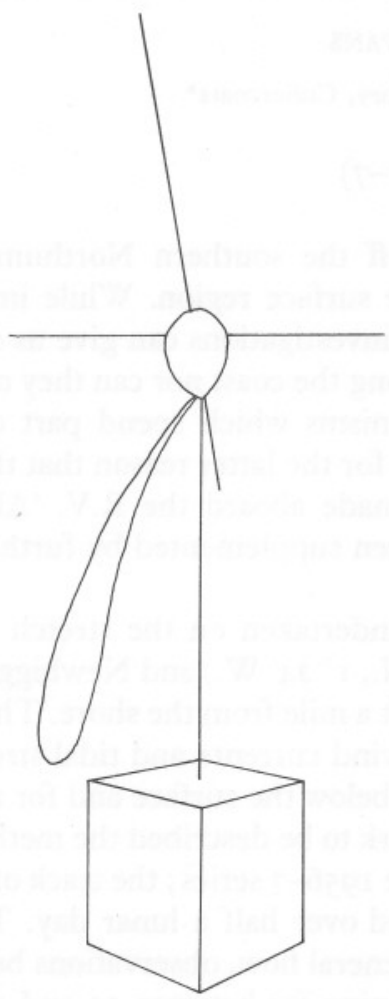

Fig. I

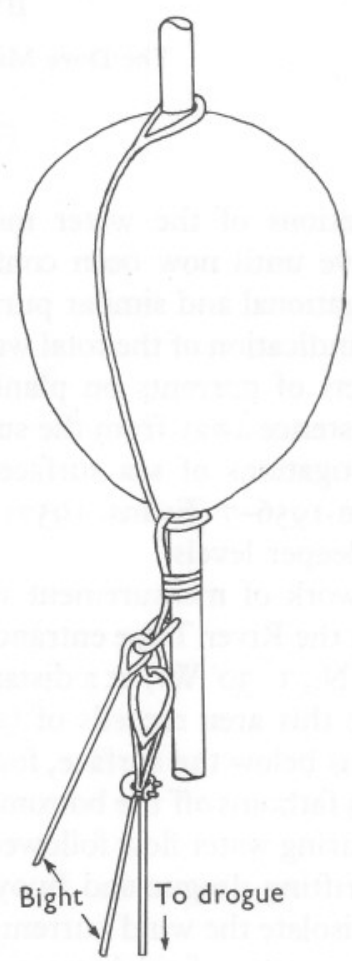

Fig. 2

Fig. I. Attachment of the drogue to the buoy for runs near the bottom.

Fig. 2. Details of the attachment of the near-bottom drogue to the buoy.

Between January and July I958, 5 runs were completed with a drogue riding at 2 fathoms' depth, 20 runs with a drogue riding at 6 fathoms' depth and 13 runs with a drogue riding about 3 fathoms off the bottom (Table 1 ). The results of the shallow water runs of 23 May and 4 July in which only a 6-fathom drogue was used have been utilized in both the 6-fathom records and those of 3 fathoms off the bottom. During the observations the mean depth of water was II 2 fathoms (Table 2 ); consequently the 2 -fathom drogue sampled near-surface currents, the 6-fathom drogue sampled mid-water currents and the drogue riding at 3 fathoms off the sea floor sampled near-bottom 
currents. For the sake of brevity, currents at these depths will therefore be referred to as near-surface, mid-water and near-bottom.

Drogue positions were fixed every $45 \mathrm{~min}$ by horizontal sextant angles of conspicuous marks ashore and, since the installation of a Decca Navigator in our ship, by an occasional Decca fix in thick weather. Wind speed and direction,

TABLE 1. WIND CURRENT AND WIND OBSERVATIONS DURING THE YEAR

(Directions are true and measured from north throughout this account)

\begin{tabular}{|c|c|c|c|c|c|c|c|c|}
\hline \multirow[b]{2}{*}{$\begin{array}{l}\text { Date } \\
\text { I958 }\end{array}$} & \multicolumn{3}{|c|}{ Set $\left({ }^{\circ}\right)$} & \multicolumn{3}{|c|}{ Drift (miles) } & \multirow{2}{*}{$\begin{array}{c}\text { Downwind } \\
\text { direction } \\
\left({ }^{\circ}\right)\end{array}$} & \multirow{2}{*}{$\begin{array}{l}\text { Downwind } \\
\text { speed } \\
\text { (knots) }\end{array}$} \\
\hline & $\begin{array}{c}\text { Near } \\
\text { surface }\end{array}$ & $\begin{array}{c}\text { Mid } \\
\text { water }\end{array}$ & $\begin{array}{c}\text { Near } \\
\text { bottom }\end{array}$ & $\begin{array}{l}\text { Near } \\
\text { surface }\end{array}$ & $\begin{array}{c}\text { Mid } \\
\text { water }\end{array}$ & $\begin{array}{c}\text { Near } \\
\text { bottom }\end{array}$ & & \\
\hline 29 Jan. & 080 & 090 & - & 0.4 & 0.3 & - & 070 & 3.7 \\
\hline I2 Feb. & I35 & 358 & - & $I \cdot 4$ & 0.5 & - & 097 & 13.5 \\
\hline 20 Feb. & 131 & 136 & - & $4 \cdot 5$ & $3 \cdot 7$ & - & II7 & 18.8 \\
\hline 4 Mar. & 112 & 128 & - & $3 \cdot 8$ & $2 \cdot 1$ & - & 090 & I $7 \cdot 4$ \\
\hline II Mar. & I39 & 247 & - & 0.6 & 0.4 & - & 124 & $7 \cdot 8$ \\
\hline 2 Apr. & - & 169 & I64 & - & 0.5 & 0.9 & 253 & $6 \cdot 0$ \\
\hline 21 Apr. & - & 128 & 129 & - & $2 \cdot 2$ & $I \cdot 2$ & 090 & $12 \cdot 3$ \\
\hline 23 Apr. & - & 357 & 340 & - & 0.7 & 0.6 & OI 8 & $12 \cdot 0$ \\
\hline $29 \mathrm{Apr}$. & - & 128 & 082 & - & I. & $I \cdot \mathbf{I}$ & 083 & 13.3 \\
\hline I May & - & 297 & 310 & - & 0.5 & 0.6 & 320 & $2 \cdot 8$ \\
\hline 8 May & - & 024 & 020 & - & 3.0 & $2 \cdot 7$ & 035 & $23 \cdot 3$ \\
\hline 9 May & - & 250 & 250 & - & 0.3 & 0.2 & 145 & $3 \cdot 7$ \\
\hline I4 May & - & 337 & 329 & - & $I \cdot 9$ & $I \cdot 7$ & 277 & $9 \cdot 6$ \\
\hline 20 May & - & 057 & 047 & - & $I \cdot I$ & 0.9 & 078 & $2 \mathrm{I} \cdot 0$ \\
\hline 23 May & - & 309 & (309) & - & $I \cdot 2$ & $(I \cdot 2)$ & 256 & $14 \cdot 3$ \\
\hline 28 May & - & 230 & 260 & - & 0.3 & 0.1 & 297 & $2 \cdot 0$ \\
\hline 30 June & - & 080 & 105 & - & 0.3 & 0.4 & 200 & $4 \cdot 3$ \\
\hline 4 July & - & I67 & (167) & - & $I \cdot \mathbf{I}$ & $(I \cdot I)$ & I98 & 13.0 \\
\hline 7 July & - & 337 & 329 & - & $I \cdot I$ & $\mathrm{I} \cdot \mathrm{O}$ & 315 & $4 \cdot 0$ \\
\hline I4 July & - & I52 & 129 & - & $2 \cdot 1$ & $2 \cdot 0$ & 096 & 16.8 \\
\hline
\end{tabular}

TABLE 2. MEAN DEPTH OF WATER DURING THE RUNS AND MEAN DEPTH OF THE NEAR-BOTTOM DROGUE

(Depths in fathoms)

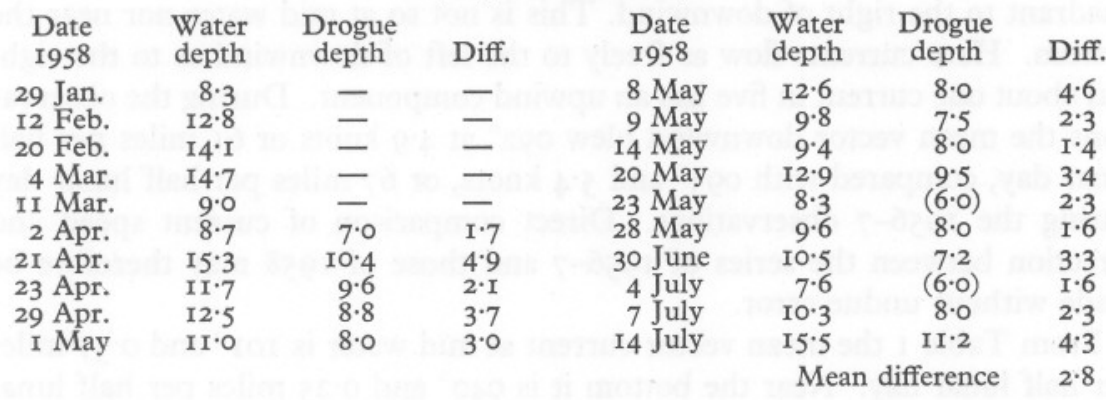

measured by anemometer and compass, were noted at each fix, and a sounding was taken. Drogues were used in pairs, sampling two depths simultaneously. While this doubled the sampling rate over that of the $1956-7$ series it possessed the disadvantage that after some hours the two drogues sometimes separated 
so much that it was impossible to supervise them both from the ship and one had to be picked up and launched again close to the other, allowance for such relaunching being made in the plot of the buoy's track. At one time I had hoped to install a radio transmitter on one of the buoys whose signal could be received on the ship's direction finder but technical difficulties prevented this.

From the results obtained wind current and tidal stream data have been derived. The wind current was taken to be the residual current of each run, since over half a lunar day the tidal streams were held to have cancelled out. The set and drift of the wind currents together with accompanying wind speed are shown in Table $\mathrm{I}$. The five near-surface results confirm

TABLE 3. DOWNWIND-CURRENT ANGLES DERIVED FROM TABLE 1

\begin{tabular}{|c|c|c|c|c|c|c|}
\hline \multicolumn{7}{|c|}{ (Angles in degrees) } \\
\hline $\begin{array}{l}\text { Date } \\
\text { 1958 }\end{array}$ & $\begin{array}{l}\text { Near } \\
\text { surface }\end{array}$ & $\begin{array}{c}\text { Mid } \\
\text { water }\end{array}$ & $\begin{array}{c}\text { Near } \\
\text { bottom }\end{array}$ & $\begin{array}{l}\text { Date } \\
\text { I } 958\end{array}$ & $\begin{array}{c}\text { Mid } \\
\text { water }\end{array}$ & $\begin{array}{c}\text { Near } \\
\text { bottom }\end{array}$ \\
\hline 29 Jan. & + Io & +20 & - & 8 May & - II & -15 \\
\hline I2 Feb. & +38 & -99 & - & 9 May & +105 & +105 \\
\hline 20 Feb. & +14 & +19 & 一 & I4 May & +60 & $\begin{array}{r}12 \\
+52\end{array}$ \\
\hline 4 Mar. & +22 & +38 & - & 20 May & $-2 I$ & $-3 I$ \\
\hline II Mar. & +15 & +123 & - & 23 May & +53 & $(+53)$ \\
\hline 2 Apr. & - & -84 & -89 & 28 May & -67 & -37 \\
\hline 2I Apr. & 一 & +38 & +39 & 30 June & -120 & -95 \\
\hline 23 Apr. & 一 & $-2 I$ & -38 & 4 July & $-3 I$ & $(-3 I)$ \\
\hline 29 Apr. & 一 & +45 & $-\mathbf{I}$ & 7 July & +22 & $+\mathrm{I} 4$ \\
\hline I May & 一 & -23 & - IO & I4 July & +56 & +33 \\
\hline \multicolumn{7}{|c|}{ Mid-water average $+5^{\circ}$} \\
\hline & & & ottom a & $-3^{\circ}$. & & \\
\hline
\end{tabular}

that surface water off the Northumberland coast moves in general into the quadrant to the right of downwind. This is not so at mid water nor near the bottom. Here currents flow as freely to the left of downwind as to the right and about one current in five has an upwind component. During the observations the mean vector downwind blew $092^{\circ}$ at 4.9 knots or 6I miles per half lunar day, compared with $093^{\circ}$ and 5.4 knots, or 67 miles per half lunar day during the $1956-7$ observations. Direct comparison of current speed and direction between the series of $1956-7$ and those of 1958 may therefore be made without undue error.

From Table $\mathrm{I}$ the mean vector current at mid water is $\mathrm{IOI}^{\circ}$ and 0.37 miles per half lunar day. Near the bottom it is $040^{\circ}$ and 0.25 miles per half lunar day. This compares with $\mathrm{II} 4^{\circ}$ and $\mathrm{I} \cdot 30$ miles per half lunar day found near the surface in I956-7. The mean vector current is thus reduced to $28 \%$ of the near-surface value at mid water and to $19 \%$ near the bottom. The average current, disregarding direction, is at mid water $\mathrm{I} \cdot 22$ miles per half lunar day and near the bottom I.05 miles per half lunar day. These are $63 \%$ and $54 \%$ 
respectively of the near-surface value of $\mathrm{I} \cdot 95$ miles per half lunar day recorded in $1956-7$.

The proportional discrepancy between the mean vector currents and nondirectional averages at the three levels is largely due to the greater directional randomness of the deeper currents. That it is not due to more random speeds of the deeper currents is shown by an examination of the simple expression wind speed/current speed. For the near-surface observations of 1956-7 we have an average value of $65^{\circ}$, for mid-water $140 \cdot 4$ and for near the bottom $145^{\circ} 4$. The coefficients of variability of these values are $56 \%, 51 \%$ and $49 \%$ respectively; i.e. randomness of wind current speed does not increase from surface to bottom.

From Table 3 the average of downwind-current angles for all observations works out to be, at mid-water $+5^{\circ}$ (current to the right of downwind) with standard deviation $63^{\circ}$, and near the bottom $-3^{\circ}$ with standard deviation $45^{\circ}$. During 1956-7 near-surface current deflexion was $+40^{\circ}$ with standard deviation $26^{\circ}$. Hence, away from the surface, deflection is less but deviation from the mean is greater. At neither mid water nor near the bottom is there a predominant current as defined in my earlier account (Evans, 1957, p. 496).

To a subscriber to Ekman's theory relating wind and ocean current direction these results are puzzling, for Ekman, it will be recalled, postulated that close to the surface a wind current would be deflected $45^{\circ}$ to the right of downwind in the northern hemisphere and that the deflexion would increase with depth. The near-surface currents, but not the deeper currents, agree with this finding. None of the later modifications to Ekman's theory, including that of a wind blowing offshore across a land barrier (Proudman, I953, p. I87) appear to remove the difficulty.

Current directions were tested against winds recorded during the $24 \mathrm{~h}$ preceding each observation, wind data being compiled from 3-hourly readings of an anemometer at Tynemouth. Agreement was poorer than with winds blowing at the time of observation. Current deflexion at mid-water was $+19^{\circ}$ with standard deviation $82^{\circ}$ and near the bottom $+6^{\circ}$ with standard deviation $95^{\circ}$. It is clear that, as with near-surface water, the onset of a given wind and the appearance of the induced current are separated by only a short interval of time.

For comparison, the 9 a.m. winds observed at sea and at Tynemouth are shown in Tables 4 \& 5. The winds encountered at sea form a good sample of the daily winds observed ashore and it is assumed that the wind currents found are likewise representative of conditions during the first 7 months of 1958 .

The measurement of tidal streams was accomplished by subtracting from the plot of each day's run that portion which represented wind current. Of necessity it was assumed that the wind current flowed steadily and in a 
constant direction throughout each run. Then, by construction (Fig. 3), it was possible to find the points of slack water had there been no wind current. The tidal stream curve off Northumberland is approximately elliptical; therefore a line joining the two points of slack water is the major axis of the ellipse and represents the mean flow of both ebb and flood streams in magnitude and direction. Such tidal stream axes had a mean orientation of $164^{\circ}-344^{\circ}$ at all depths, maximum deviations being $\pm 17^{\circ}$. Since the bearing of Newbiggin Point from the North Tyne Light is $343^{\circ}$ the mean flow of tidal streams, unlike that of wind currents, is seen to be parallel to the coast.

TABLE 4. 9 A.M. WIND FORCES AT TYNEMOUTH AND AT SEA, EXPRESSED AS PERCENTAGE OF TOTAL OBSERVATIONS

$\begin{array}{lrr}\text { Observations } & \begin{array}{c}\text { At Tynemouth } \\ 212\end{array} & \begin{array}{c}\text { At sea } \\ 20\end{array} \\ \text { Calm } & 5 \cdot 7 & \\ \text { Force I } & 10.8 & 5 \\ \text { Force 2 } & 14.6 & 5 \\ \text { Force 3 } & 25.0 & 20 \\ \text { Force 4 } & 27.6 & 25 \\ \text { Force 5 } & 9.9 & 25 \\ \text { Force 6 } & 4.2 & 5 \\ \text { Force 7 } & 0.5 & 15 \\ \text { Force 8 } & 1.9 & 0 \\ & & 0\end{array}$

TABLE 5. 9 A.M. DOWNWIND DIRECTIONS AT TYNEMOUTH AND AT SEA, EXPRESSED AS PERCENTAGE OF TOTAL OBSERVATIONS

$\begin{array}{lcc}\text { Observations } & \begin{array}{c}\text { At Tynemouth } \\ 212\end{array} & \begin{array}{c}\text { At sea } \\ 20\end{array} \\ \text { Calm } & 5 \cdot 4 & \\ 000^{\circ}-089^{\circ} & 24.0 & 5 \\ 090^{\circ}-179^{\circ} & 37 \cdot 3 & 15 \\ 180^{\circ}-269^{\circ} & 14.6 & 45 \\ 270^{\circ}-359^{\circ} & 18.4 & 25 \\ & & 10\end{array}$

The magnitude of the major axis of the tidal stream ellipse may appropriately be called the stream range, corresponding to the vertically measured tidal range. The stream range is found to vary rather less in proportion over the three levels than the wind currents. Near the surface 25 observations including those of 1956-7 yield an average range of 2.8 miles, at mid-water the range averages 2.7 miles and near the bottom, 2.5 miles.

Stream range varies under soli-lunar influence in the same manner as tidal range. Relationships have been established between stream range and predicted tidal range at the Tyne entrance. In Figs. 4-6 the stream range is compared with the mean tidal range for each day of observation. Regression lines are plotted for the following values: near the surface $t=5 \cdot 3+\mathrm{I} \cdot 88 \mathrm{~s}$; at mid-water $t=4 \cdot 9+2.29 \mathrm{~s}$; and near the bottom $t=6.8+\mathrm{r} \cdot 79 \mathrm{~s}$; where $t$ is the predicted tidal range in feet and $\mathrm{s}$ the stream range in miles. 
If the mean tidal range at the Tyne entrance is taken as II ft, then by Figs. 4-6 the mean stream range is 3.03 miles near the surface, 2.66 miles at midwater and 2.35 miles near the bottom. Thus under average and parallel tidal conditions the stream range near the surface is about 0.4 miles greater than at mid-water and about 0.7 miles greater than near the bottom.

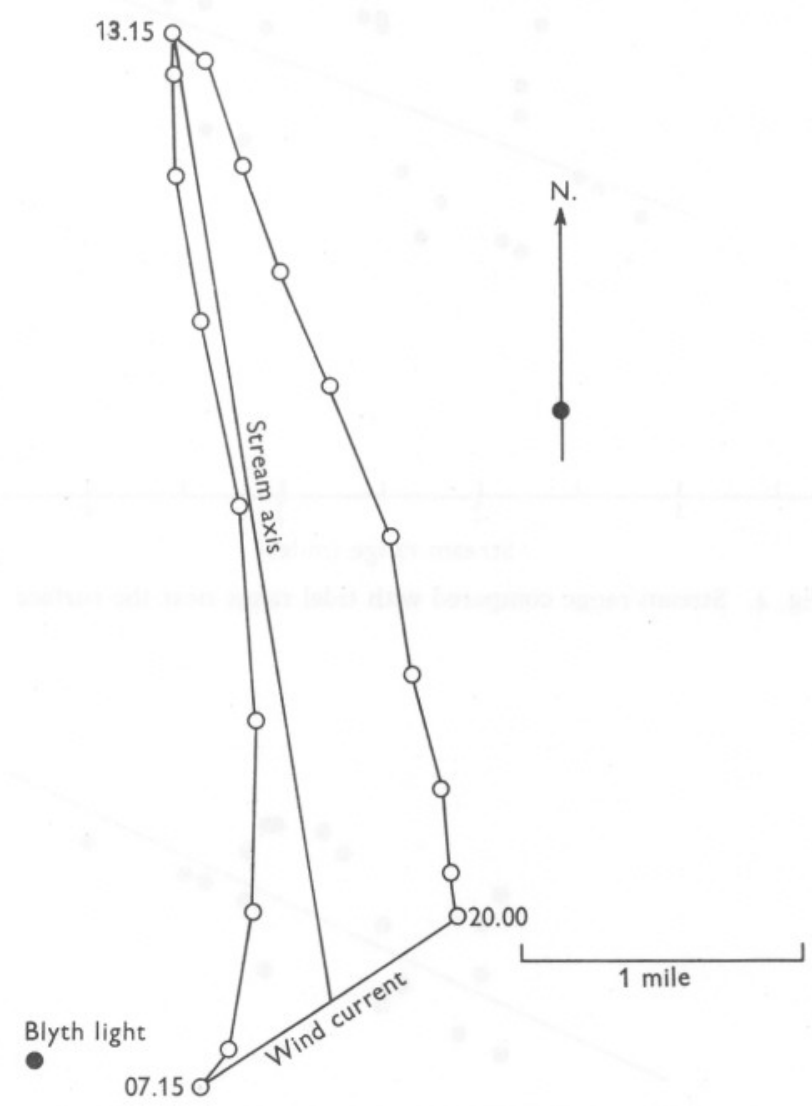

Fig. 3. Plot of the mid-water run of 20 May 1958 showing the extraction of wind current and stream range.

As a footnote to the stream range data the following may throw some light on the manner and time at which drifting material and the larvae of littoral animals are brought ashore on the Northumberland coast. (Until currents in and near the surf zone have been studied the final track before grounding must remain conjectural.) Near the surface the shape of the tidal stream ellipse is largely obscured by the wind current. The prevailing westerly wind combined with Coriolis force produces a predominant current moving southwards along the coast and somewhat offshore. Away from the surface, 


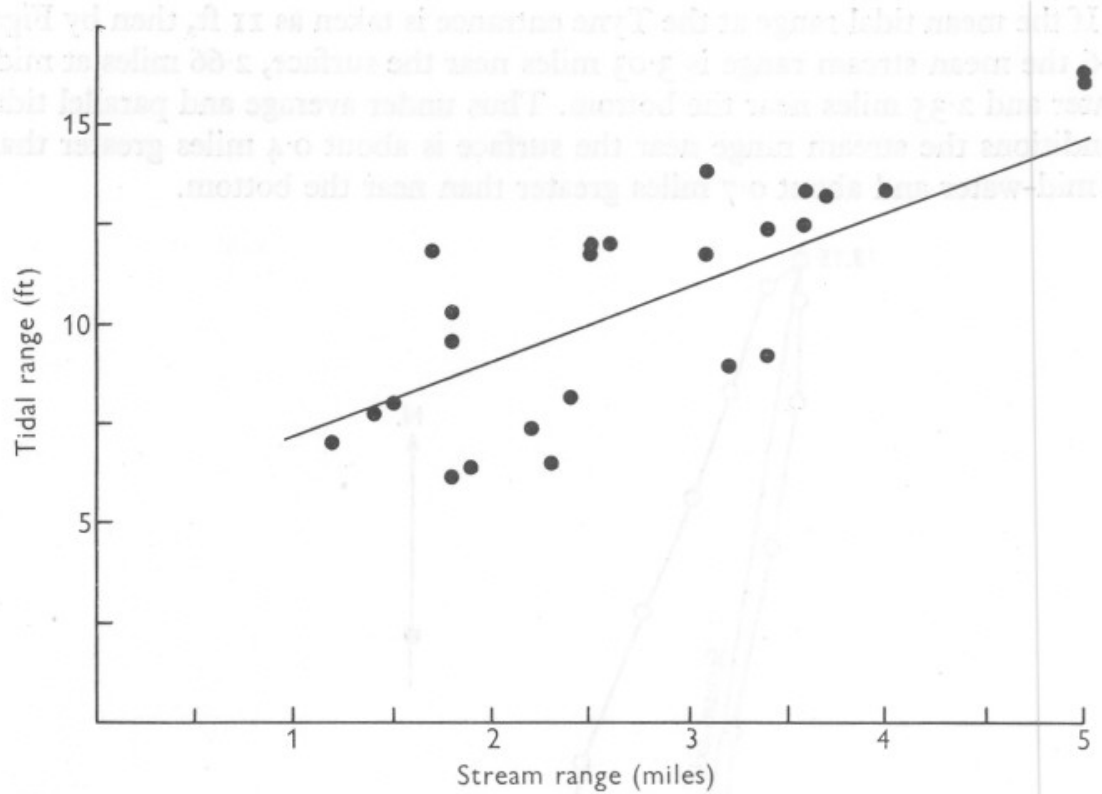

Fig. 4. Stream range compared with tidal range near the surface.

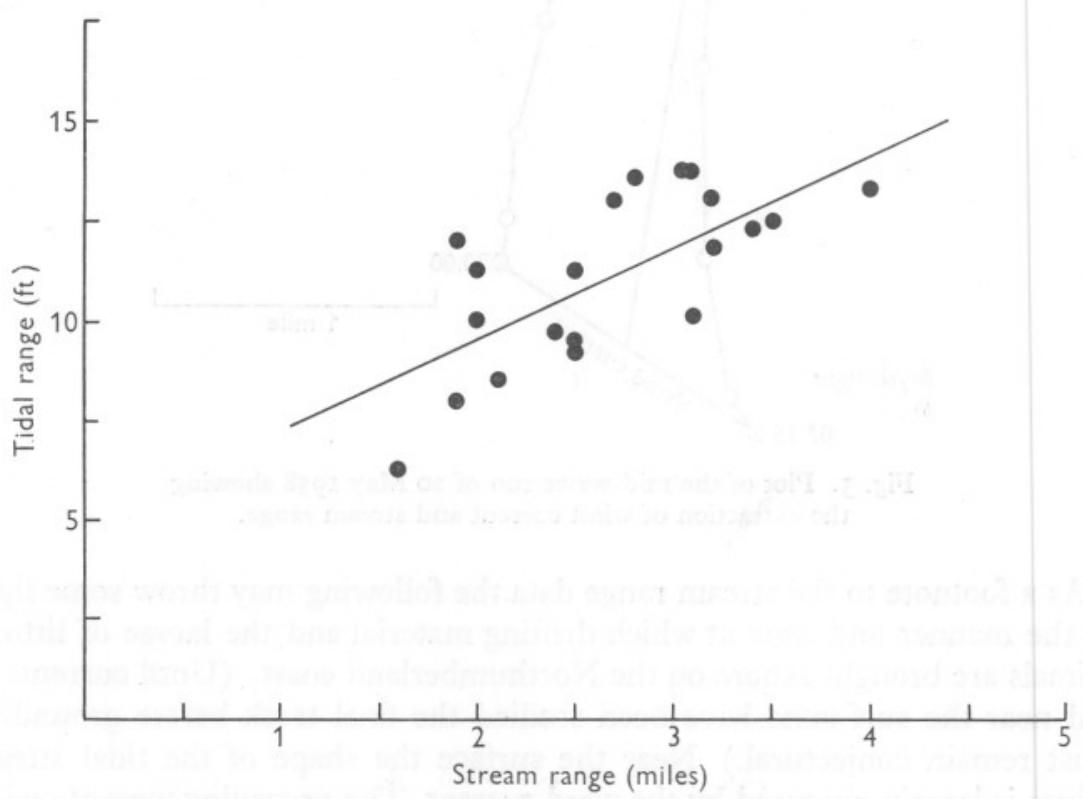

Fig. 5. Stream range compared with tidal range at mid-water. 
however, where the wind current is less strong, true stream movement becomes more apparent. Off Northumberland still water is rarely encountered and at the period referred to as slack water the stream, having attained its maximum reach northwards or southwards along the coast, is setting either onshore or offshore. From Table 6 it is seen that while the near-surface water usually turns offshore at each slack water this tendency is modified at mid-water and

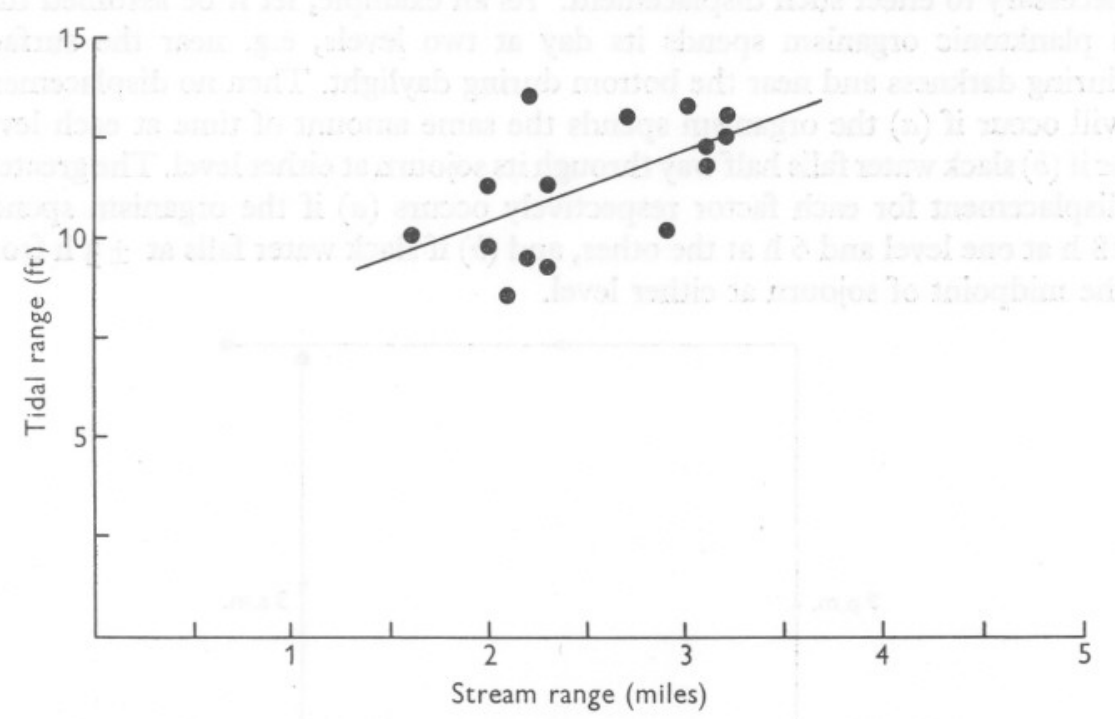

Fig. 6. Stream range compared with tidal range near the bottom.

TABLE 6. 120 OBSERVATIONS OF THE TURN OF THE TIDE OFF NORTHUMBERLAND

\begin{tabular}{|c|c|c|c|c|}
\hline & \multicolumn{2}{|c|}{ Flood end } & \multicolumn{2}{|c|}{ Ebb end } \\
\hline & Offshore & Onshore & Offshore & Onshore \\
\hline Near surface & 20 & 5 & I8 & 7 \\
\hline & I2 & 8 & 7 & 13 \\
\hline fear bottom & IO & 5 & 3 & 12 \\
\hline
\end{tabular}

near the bottom, and as the depth increases a pattern of onshore sets at the end of the ebb and offshore sets at the end of the flood becomes manifest, i.e. the stream ellipse has an anticlockwise sense. This is in agreement with Doodson \& Warburg's (I94I, p. I79) analysis of the behaviour of a progressive wave having a shelving coast on the right of its direction of travel. Such a pattern suggests that drifting and suspended material would tend to ground at the end of the ebb, which in the region under consideration is about $2 \frac{1}{2} \mathrm{~h}$ after low water at the Tyne entrance, low water and slack water being there separated by this interval. 
Both wind currents and tidal streams may effect a permanent displacement of position of planktonic organisms. This is obviously so for wind currents but less so for tidal streams, whose mean vector is zero. In the latter case it is brought about by the combination of differing stream ranges at different levels and the vertical movement of plankton (which, off Northumberland, takes place readily in Io fathoms of water and less). Even so, certain conditions are necessary to effect such displacement. As an example, let it be assumed that a planktonic organism spends its day at two levels, e.g. near the surface during darkness and near the bottom during daylight. Then no displacement will occur if $(a)$ the organism spends the same amount of time at each level or if $(b)$ slack water falls half way through its sojourn at either level. The greatest displacement for each factor respectively occurs $(a)$ if the organism spends $\mathrm{I} 8 \mathrm{~h}$ at one level and $6 \mathrm{~h}$ at the other, and $(b)$ if slack water falls at $\pm 3 \mathrm{~h}$ from the midpoint of sojourn at either level.

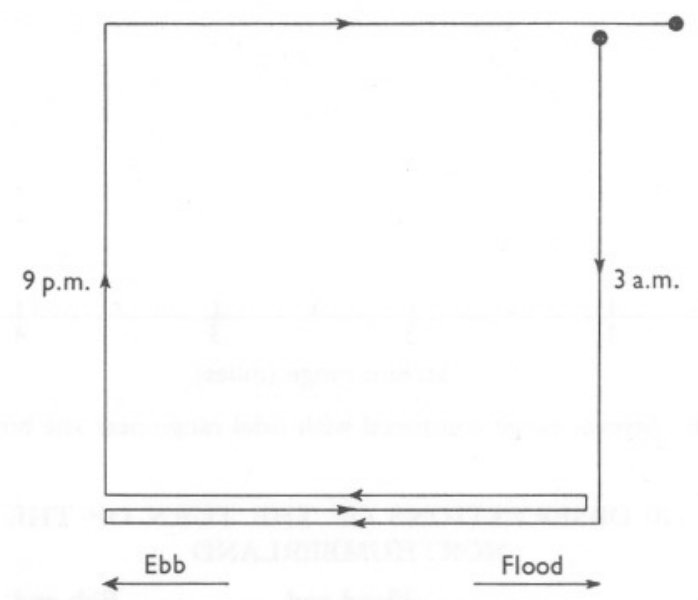

Fig. 7. The tidal stream forces acting on a planktonic organism which migrates vertically at 3 a.m. and 9 p.m. slack waters.

To illustrate this (Fig. 7), with the end of flood occurring at 3 a.m., if a planktonic organism retires to near the bottom at this time and returns to near the surface at 9 p.m. then over a day it will spend two ebb streams and one flood stream near the bottom and one flood stream near the surface. Since stream range is, on average, 0.7 miles greater near the surface than near the bottom it will, in a day and by stream influence alone, be moved this average distance southwards along the Northumberland coast.

In addition it may be noted that tidal streams, whose mean vectors at any one level are zero, may yet affect the spatial separation of pairs of planktonic organisms, provided such organisms undertake vertical migration at different times of day; tidal streams, like wind currents, can thus contribute to patterns of plankton distribution. 
With the aid of the foregoing information and armed with records of wind, tidal range and hours of daylight it is possible to plot for a small number of days the movement of plankton along the Northumberland coast, together with some estimate of the error in our final position. Using local weather forecasts we may also attempt short-term prognosis. Over the short intervals envisaged the wind speed/current speed and stream range/tidal range relationships should be employed, not the mean vectors.

\section{TABLE 7. FREQUENCY DISTRIBUTION OF REPRESENTATIVE ANIMALS} TAKEN BY VERTICAL HENSEN NET

29 Jan.

Nyctiphanes couchii

Sagitta elegans

Calanus finmarchicus

$\begin{array}{llllllll}08.00 & 09.30 & 11.00 & 12.30 & 14.00 & 15.30 & 17.00\end{array}$

12 Feb.

Nyctiphanes couchii

Sagitta elegans

Calanus finmarchicus

$\begin{array}{rr}\circ & 0 \\ \circ & 2 \\ 27 & 10\end{array}$

$\begin{array}{rrrrr}8 & 4 & 0 & 8 & 12 \\ 2 & 6 & 2 & 2 & 2 \\ 58 & 96 & 99 & 45 & 40\end{array}$

20 Feb.

Nyctiphanes couchii

Sagitta elegans

Calamus finmarchicus

$\begin{array}{rr}14 & 123 \\ 8 & 16 \\ 198 & 155\end{array}$

$\begin{array}{rrrr}259 & 117 & 69 & 197 \\ 29 & 30 & 19 & 17 \\ 287 & 277 & 251 & 522\end{array}$

4 Mar.

Nyctiphanes couchii

Sagitta elegans

Calanus finmarchicus

$\begin{array}{rrr}3 & 4 & 30 \\ 1 & 24 & 35 \\ 23 & 33 & 145\end{array}$

$\begin{array}{rrrr}76 & 21 & 271 & 103 \\ 74 & 33 & 38 & 20 \\ 269 & 66 & 414 & 254\end{array}$

II Mar.

Nyctiphanes couchii

Sagitta elegans

Calanus finmarchicus

$\begin{array}{rrrrrrr}2 & 0 & 0 & 27 & 5 & 54 & 77 \\ 1 & 8 & 3 & 9 & 13 & 9 & 8 \\ 5 & 2 & 1 & 13 & 33 & 72 & 13\end{array}$

Plankton in the Northumberland seas is unevenly distributed as it is elsewhere. Anraku (1956) has shown that uneven distribution occurs within very small limits of sampling. During the present work small-scale patchiness was again shown during attempts to secure replicate plankton samples from close beside the mid-water drogue. Samples were taken at $\mathrm{I} \frac{1}{2} \mathrm{~h}$ intervals on 5 days, with a Hensen net which was hauled vertically from bottom to surface. By hauling the net close to the mid-water drogue much the same water was fished on each occasion, especially in the deeper regions where the bulk of the plankton was known to be lying. The frequency distribution of a few representative planktonic animals is shown in Table 7. Clearly, even allowing for small changes in depth, the uneven distribution of plankton extends to smaller limits than these.

What follows is presented as a promising but so far poorly pursued line of enquiry into plankton patchiness. It is concerned with the turbulent 
nature of all sea current flow (Sverdrup, Johnson \& Fleming, I956, p. 90). Turbulence has the effect of altering the spatial relationships of water particles in a random manner; it is that diffusing component of flow (Ludlam \& Scorer, 1954) which leads to the dispersal or aggregation of particles in a turbulent medium.

In August 1958 small-scale turbulence in water movement off Northumberland was encountered during an investigation of the accuracy of individual current measurements using drogues. Pairs of drogues used in the studies of gross currents were employed, both drogues being set to ride 6 fathoms below the surface. They were launched together one mile east of Blyth Light in Io fathoms of water and their tracks were plotted over a period of $2 \mathrm{~h}$. The bearing and distance of one drogue from the other was ascertained by bringing the ship in transit with the buoys and taking a compass bearing and vertical

TABLE 8. SEPARATION OF A PAIR OF DROGUES OVER TWO HOURS

(Separation in feet)

\begin{tabular}{|c|c|c|c|c|c|c|c|c|c|}
\hline \multirow[b]{2}{*}{ Date } & \multicolumn{5}{|c|}{ Time interval (minutes) } & & & \multirow{2}{*}{$\begin{array}{l}\text { Current } \\
\text { speed } \\
\text { (knots) }\end{array}$} & \multirow{2}{*}{$\begin{array}{l}\text { Wind } \\
\text { speed } \\
\text { (knots) }\end{array}$} \\
\hline & $\circ$ & 20 & 40 & 60 & 80 & 100 & 120 & & \\
\hline 5 Aug. & 25 & 95 & 80 & 135 & 125 & 140 & I90 & 0.5 & 9 \\
\hline 6 Aug. & 15 & 40 & 60 & 75 & 50 & 65 & 75 & 0.2 & 13 \\
\hline 7 Aug. & 15 & 25 & 40 & 50 & 95 & 130 & 145 & 0.2 & 12 \\
\hline 8 Aug. & I5 & 60 & 45 & 100 & 90 & I30 & I40 & 0.2 & 5 \\
\hline I I Aug. & 25 & 50 & 60 & 45 & 75 & 85 & 105 & 0.3 & 2 \\
\hline I2 Aug. & 40 & 45 & 70 & 75 & 95 & 85 & 140 & 0.3 & I \\
\hline I3 Aug. & 20 & 15 & 0 & 0 & 25 & 60 & 55 & 0.2 & 5 \\
\hline I4 Aug. & 35 & Io & 40 & 70 & 95 & I45 & 170 & 0.4 & II \\
\hline I5 Aug. & 25 & I65 & I55 & 460 & 690 & 660 & 840 & 0.7 & 6 \\
\hline I8 Aug. & 15 & 30 & 5 & 25 & 65 & IIO & 130 & $I \cdot O$ & 6 \\
\hline
\end{tabular}

sextant angle of the buoy poles which were $7 \cdot 5 \mathrm{ft}$ long. Distances were then extracted from table I5 of the Admiralty Manual of Hydrographic Surveying (1952). Runs with pairs of drogues were made on ro occasions (Table 8); the maximum separation of the two drogues occurred on 15 August and was $840 \mathrm{ft}$. In view of the identical form of the buoys and drogues their separation can best be explained by invoking the principle of turbulent flow known to be associated with all sea currents.

The number of observations is too small for detailed statistical treatment and the results give little more than a qualitative impression of the turbulent forces present. Stommell (1949), in reviewing studies of turbulence, notes that by the so-called ' $4 / 3$ law' dispersing forces increase as the separation between particles grows. Off Northumberland the separation during the second hour averaged I I I 7 times that of the first hour, and the mean separation after $2 \mathrm{~h}$ was $200 \mathrm{ft}$. This suggests that separation after half a lunar day averages at least $\frac{1}{4}$ mile.

From the results of these studies the proposition is advanced that, regardless of other factors, the combination of varying wind currents and tidal streams, 
turbulent flow, and the vertical migration of much of the plankton ensures that plankton distribution off Northumberland is of a dynamic and irregular nature; and that even when the intrinsic behaviour of the planktonic organisms is left out of account there remains a tendency directed towards patchiness.

My acknowledgements are due to the Coast Guards of Tynemouth for providing wind records. I remain greatly indebted to Skipper R. Harrison of the R.V. 'Alexander Meek' for his extensive co-operation in this work.

\section{SUMMARY}

Using free drogues observations have been made of the wind currents and tidal streams at three depths off the Northumberland coast. Records of current speed and direction for the near-surface, mid-water and near-bottom levels are given, together with tidal stream ranges. A relationship is established between wind current and wind, and between stream range and tidal range. Using pairs of drogues the characteristics of oceanic turbulence over a short period were investigated. The relationship of all these factors to plankton patchiness is considered.

\section{REFERENCES}

Admiralty Manual of Hydrographic Surveying, 1952. London: H.M.S.O.

ANRAKU, M., I956. Some experiments on the variability of horizontal plankton hauls and on the horizontal distribution of plankton in a limited area. Bull. Fac. Fish. Hokkaido Univ., Vol. 7, No. I.

Doodson, A. T. \& WARBURG, H. D., I94I. Admiralty Manual of Tides. London: H.M.S.O.

Evans, F., 1957. Sea currents off the Northumberland coast. F. mar. biol. Ass. U.K., Vol. 36, pp. 493-9.

Ludlam, F. H. \& SCORER, R. S., 1954. Further Outlook. London: Allan Wingate.

Proudman, J., 1953. Dynamical Oceanography. London: Methuen.

Stommell, H., I949. Horizontal diffusion due to oceanic turbulence. F. mar. Res., Vol. 8, pp. 199-225.

Sverdrup, H. U., Johnson, M. W. \& Fleming, R. H., 1946. The Oceans, Their Physics, Chemistry, and General Biology. New York: Prentice-Hall. 